Check for updates

Cite this: RSC Adv., 2018, 8, 3736

\title{
Chitosan composite scaffolds for articular cartilage defect repair: a review
}

\author{
Huijun Li, (D) abcd Cheng Hu, ${ }^{\text {ad }}$ Huijun Yu (DD *abc and Chuanzhong Chen (D) *ad
}

Articular cartilage (AC) defects lack the ability to self-repair due to their avascular nature and the declined mitotic ability of mature chondrocytes. To date, cartilage tissue engineering using implanted scaffolds containing cells or growth factors is the most promising defect repair method. Scaffolds for cartilage tissue engineering have been comprehensively researched. As a promising scaffold biomaterial for AC defect repair, the properties of chitosan are summarized in this review. Strategies to composite chitosan with other materials, such as polymers (including collagen, gelatin, alginate, silk fibroin, polycaprolactone, and poly-lactic acid) and bioceramics (including calcium phosphate, calcium polyphosphate, and hydroxyapatite) are presented. Methods to manufacture three-dimensional porous structures to support cell attachment and nutriment exchange have also been included.

Received 20th October 2017 Accepted 26th December 2017

DOI: 10.1039/c7ra11593h

rsc.li/rsc-advances of movable bones. ${ }^{1}$ Cartilage tissues play a significant role in human health and normal life. Nevertheless, many risk factors can injure these tissues, such as natural degradation, traumatic, posttraumatic, and degenerative disease. The lack of blood supply to cartilage and the low mitotic ability of chondrocytes results in the poor self-repair ability of articular cartilage (AC). ${ }^{2}$ Therefore, a method to assist the repair of damaged cartilage tissues with few side effects is urgently needed.

Due to the special structure and properties of cartilage tissues, effective methods for their defect repair have yet to be found. Existing autologous or allograft implantation methods have drawbacks, such as a lack of material source, long recovery time ${ }^{3}$ immunological rejection, and cross infection with donors. To address these issues, cartilage tissue engineering has been developed and its advantages demonstrated. In the repair process, scaffolds guide the migration of target cells,

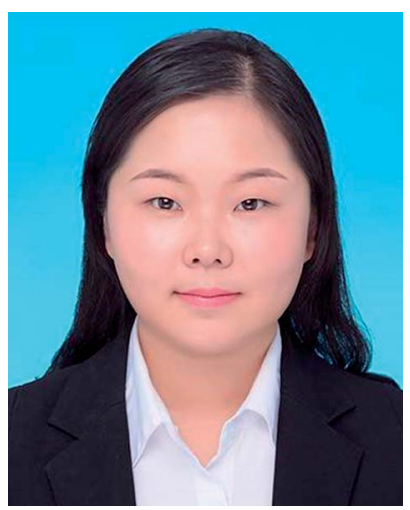

Huijun Li completed her Bachelors degree at Ocean University, China, in 2014. She is currently a Masters student at the Key Laboratory for Liquid-Solid Structural Evolution and Processing of Materials (Ministry of Education), School of Materials Science and Engineering, Shandong University. Her main field of research is biomaterials.

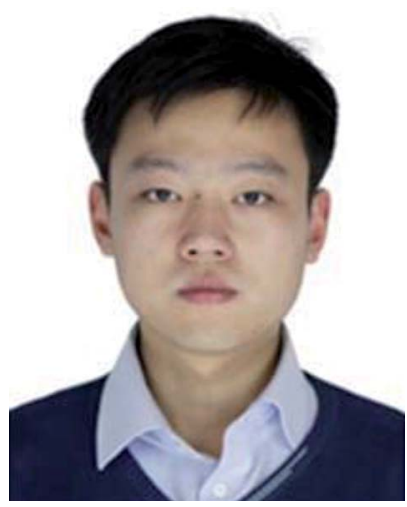

Cheng Hu completed his PhD at School of Chemical Engineering, The University of Adelaide in 2015. After two years of post-doc at School of Science, Loughbourgh University, he moved to Key Laboratory for Liquid-Solid Structural Evolution and Processing of Materials (Ministry of Education), School of Materials Science and Engineering, Shandong University. His research interests include porous functional materials, surface engineering and electrochemical energy storage. 
such as chondrocytes, to the injury site and stimulate their growth and differentiation, finally degrading in response to matrix remodeling enzymes released by cells as tissue repair progresses. ${ }^{4}$ Cartilage tissue engineering can create a more durable and functional replacement of the degenerated tissue in vivo. Furthermore, the regenerated tissue is more likely to survive mechanical conditions in the joint. ${ }^{5}$

As a promising biomaterial, chitosan (CS) has outstanding bioactivities, antimicrobial properties, ${ }^{6}$ non-toxicity, ${ }^{7}$ biocompatibility, ${ }^{8}$ biodegradability, ${ }^{9}$ and superior physical properties. ${ }^{10}$ The application of CS has been studied in many areas, such as wound healing, ${ }^{11}$ drug delivery, tissue engineering, ${ }^{12}$ and water treatment. CS can be processed into diverse forms, including gels, films, fibers, and sponges. ${ }^{\mathbf{1 3}, 14}$ In particular, the hydroxyl groups of chitosan make it easy to composite with other materials.

The tissue engineering approach to repair and regeneration is based on the use of polymer scaffolds, which serve to support, reinforce, and, in some cases, organize the regenerating tissue. ${ }^{15}$ To date, various materials for cartilage tissue engineering have been developed, including polymers such as chitosan $^{\mathbf{1 6}}$ and collagen, ${ }^{17}$ and bioceramics, such as calcium phosphate ceramic and hydroxyapatite. ${ }^{18}$ Natural or naturederived polymers belong to the natural living body constitution. The main advantages of natural polymers are biocompatibility, and their degraded products are non-toxic when implanted. Some natural polymers also possess the ability to activate gene expression. However, sources of natural polymers are limited and usually require complex post-processing. The main advantages of synthetic polymers are their superior mechanical properties, high porosity for chondrocyte and cartilage tissue growth, and adjustable properties. However, biological compatibility is a weakness of synthetic polymers when applied to cartilage tissue engineering. Furthermore, bioceramics exhibit excellent physical properties, but their fragility and degradation properties limit applications in AC defect repair. Much effort have been made to develop scaffolds with porous interconnected network structures and the

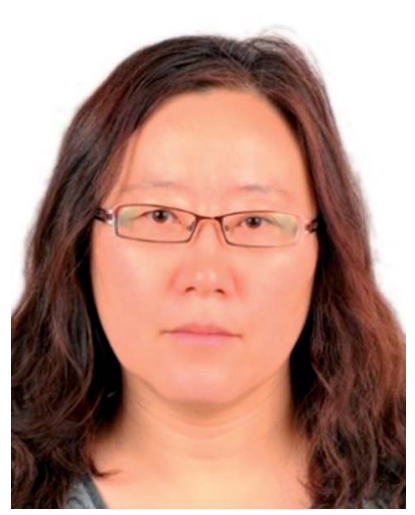

Huijun Yu completed her Masters degree in Mechanical Engineering at Shandong University in 1991. She is currently an Associate Professor at the Key Laboratory of HighEfficiency and Clean Mechanical Manufacture (Shandong University), Ministry of Education, School of Mechanical Engineering, Shandong University. Her main fields of research are micro-arc oxidation, laser surface modification, and biomaterials. She has published more than 50 papers in reputed journals. necessary mechanical strength to support the cell attachment, proliferation, and differentiation toward repairing the AC defect. ${ }^{19}$ Successful cartilage tissue engineering requires a biologically compatible and degradable scaffold with desired structural features for cell attachment. ${ }^{20}$ This paper summarizes CS composite scaffolds that have been investigated recently.

\section{Articular cartilage defect repair}

AC is a biphasic, viscoelastic, porous, and permeable material with unique biomechanical properties. ${ }^{21} \mathrm{AC}$ is made up of chondrocytes distributed into the extracellular matrix (ECM). The ECM is composed of different types of collagens (mainly type II), proteoglycan, and non-collagenous proteins. ${ }^{22}$ The ECM occupies the vast majority of the tissue (more than 95\%), and acts as the function element, ${ }^{23}$ as shown in Fig. 1. Chondrocytes play a key role in building AC during development. ${ }^{24}$ However, the ability of chondrocytes in $\mathrm{AC}$ to repair and regenerate ${ }^{25}$ is gradually reduced with increasing age, while the cell density of chondrocytes in AC also decreases progressively. For instance, chondrocytes only account for about $1 \%$ of the volume of hyaline cartilage. ${ }^{26} \mathrm{AC}$ can be divided into four zones based on the changing mechanical environment. From the surface to inner tissue connecting with subchondral bone, mechanical stress caused by fluid flow and compressive strains becomes gradually weaker, while fluid pressure increases, making the density, porosity, and form of chondrocytes differ significantly from each other. These zones are referred to as the superficial zone, middle zone, deep zone, and calcified zone, as shown in Fig. $2 .^{24,27}$

The main types of cartilage injury can be classified into partial-thickness and full-thickness defects. Self-healing after defects involves the tissue itself and adjacent tissues. ${ }^{24}$ Mature chondrocytes, the only kind of cells found in AC, lack the ability to repair and regenerate. In partial-defects, the calcified cartilage prevents adjacent cells from permeating into the void. In full-thickness defects, the damage runs through the AC, penetrating into the subchondral bone marrow, ${ }^{28}$ allowing blood

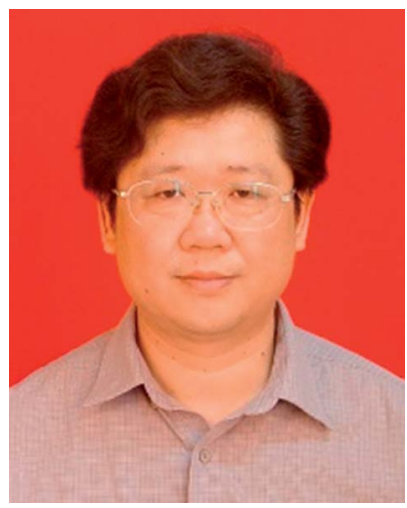

Chuanzhong Chen completed his PhD in Materials Science at Harbin Institute of Technology in 2001. He is currently a Professor at the Key Laboratory for Liquid-Solid Structural Evolution and Processing of Materials (Ministry of Education), School of Materials Science and Engineering, Shandong University. His main fields of research are micro-arc oxidation, laser surface modification, and biomaterials. He has published more than 200 papers in reputed journals and serves as an editorial board member for Surface Technology. 
articular cartilage extracellular matrix

functional element

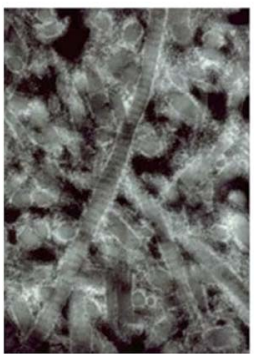

chondrocytes reactive element

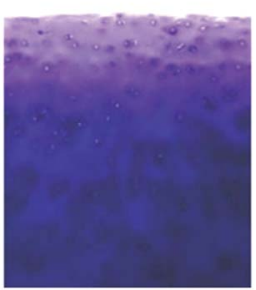

Fig. 1 Constitution of articular cartilage..$^{23}$

from the marrow to bring cells and fibrin that can form repair tissue similar to native cartilage overflow into the lesion. However, this regenerated tissue always degrades within 6-12 months ${ }^{28}$ meaning recovery is only temporary. Therefore, in general, AC tissue possesses little self-repair ability.
Cartilage tissue engineering seeks to repair voids or lesions by implanting biomaterial scaffolds containing cells and stimulating factors that can act as a substitute for native AC $\mathrm{ECM}^{24}$ and simulate the chondrocyte survival environment. ${ }^{29,30}$

\section{Chitosan as a biomaterial}

Chitosan (poly- $\beta$-1,4-linked glucosamine, CS) is a cationic polysaccharide made from alkaline $N$-deacetylation of chitin. ${ }^{31}$ Sources of chitin are abundant in nature, such as crustacean shells, insect cuticles (mainly from shrimps and crabs), and fungi cell walls. ${ }^{32} \mathrm{CS}$ is a linear polysaccharide consisting of $\beta$ linked D-glucosamine residues with a variable number of randomly located $N$-acetylglucosamine groups. ${ }^{33}$ The molecular structure of chitosan is similar to that of some polysaccharide repeating units in AC, as shown in Fig. $3,{ }^{\mathbf{1 3}, 34}$ making the characteristics of chitosan similar to those of hyaluronic acid and glycosaminoglycan (GAG) in the ECM. ${ }^{30}$ Therefore, CS can simulate the articular cartilage ECM to some extent and could promote the formation of cartilage tissue. As a result, chitosan is a promising natural biomaterial scaffold for cartilage defect

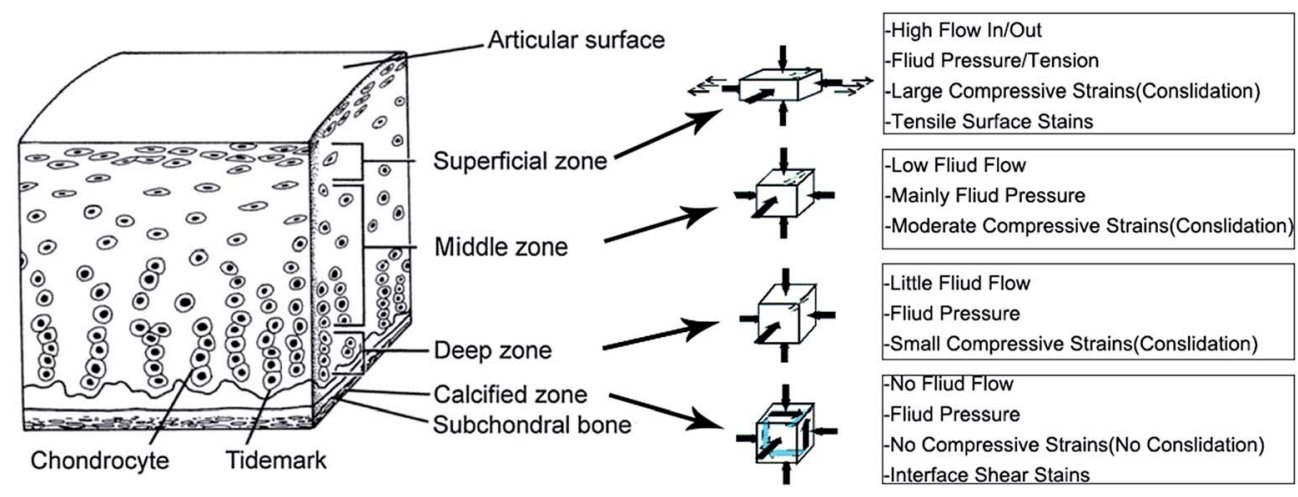

Fig. 2 Structure of adult articular cartilage and the in vivo mechanical environment. ${ }^{24,27}$

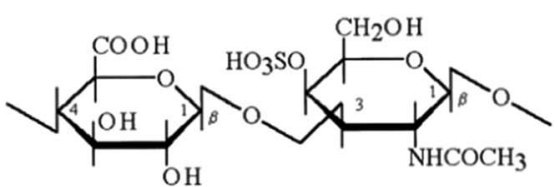

(a) Chodroitin 4-Sulfate

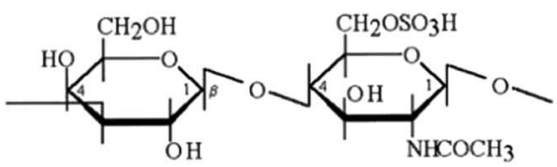

(c) Keratan Sulfate

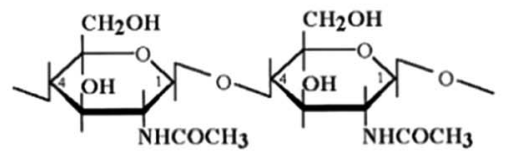

(e) Chitin

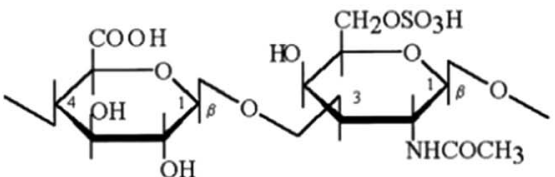

(b) Chondoitin 6-Sulfate

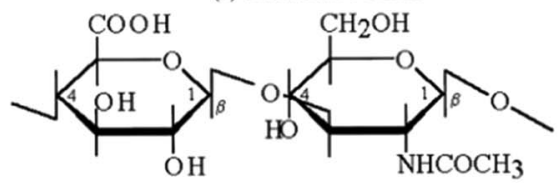

(d) Hyarulonate

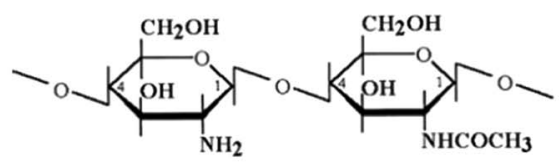

(f) Chitosan

Fig. 3 Molecular structures of some polysaccharide repeating units and chitosan. ${ }^{13,34}$ 
Table 1 Bioactivities of chitosan

\begin{tabular}{|c|c|c|}
\hline Bioactivity & Reasons & Mechanisms \\
\hline Antimicrobial activity & Cationic nature & $\begin{array}{l}\text { (1) Low molecular weight }\left(M_{\mathrm{W}}\right) \text { chitosan penetrates bacterial walls, binds with DNA, } \\
\text { and prevents gene expression } \\
\text { (2) High } M_{\mathrm{W}} \text { chitosan binds with negatively charged components on the bacterial cell wall, } \\
\text { forming a polymer membrane that prevents nutrients from entering the cell }{ }^{38}\end{array}$ \\
\hline Antitumor activity & $\begin{array}{l}\text { Stimulating hormone } \\
\text { secretion and cells mature }\end{array}$ & $\begin{array}{l}\text { (1) Increased lymphokine production resulting in proliferation of cytolytic T-lymphocytes } \\
\text { (2) Causes maturation or infiltration of macrophages and cytolytic T-lymphocytes and } \\
\text { suppresses tumor growth }\end{array}$ \\
\hline
\end{tabular}

repair. ${ }^{35}$ Furthermore, the positive charge on chitosan could facilitate scaffold binding to negatively charged tissue cells or body fluid.

\subsection{Bioactivities of chitosan}

The bioactivities of chitosan are mainly reflected in its antimicrobial, antitumor, and antioxidant activities. These mechanisms are shown in Table 1. Park et al. ${ }^{36}$ examined a chitosan series against different types of Gram-negative and Grampositive bacteria, with chitosan showing better antimicrobial activity against Gram-negative bacteria, including E. coli, $P$. aeruginosa, and $S$. typhimurium due to its cationic nature.
Sudarshan et al. $^{37}$ explored the antibacterial action of three kinds of chitosan, as shown in Fig. 4. The CS solution significantly inactivated Enterobacter aerogenes and Staphylococcus aureus, with the degree of deactivation related to the type or concentration of the chitosan solution. Zivanovic et al. ${ }^{\mathbf{4 1}}$ tested the antibacterial properties of chitosan composite film towards Escherichia coli $\mathrm{K}-12$, using phosphate buffer with no film and phosphate buffer/film with no inoculum acted as controls. The results showed that chitosan was endowed with antibacterial properties.

The bioactivities of chitosan help to reduce inflammation when chitosan scaffolds are used for AC defect repairs. The
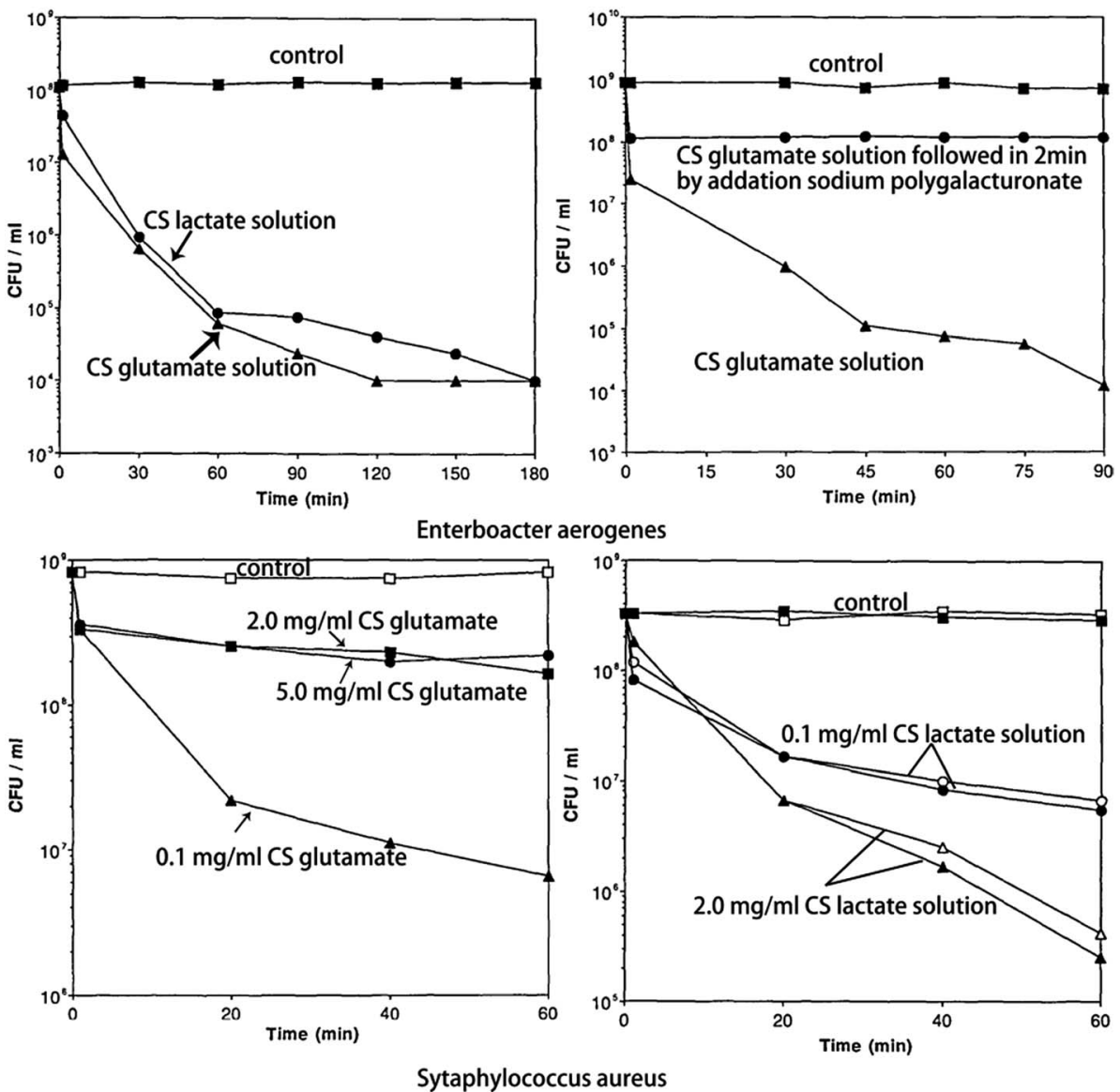

Fig. 4 Treatment of Enterobacter aerogenes and Staphylococcus aureus with different types of chitosan solution. ${ }^{37}$ 
research of Oprenyeszk et al. ${ }^{42}$ confirmed that the production of inflammatory mediators IL-6 $(p=0.0012)$, IL-8 $(p<0.0001)$, and PGE2 $(p=0.0056)$ by chondrocytes was significantly reduced by the addition of chitosan after a 3 day culture. Furthermore, this significant inhibitory effect was sustained during a culture period of 17-21 days. Moreover, oxidative stress of cells and tissues led to cell death and tissue injury, and maximized inflammation, ${ }^{\mathbf{4 3}}$ which could hinder tissue wound healing. Therefore, the inherent antioxidant activity of chitosan is important for tissue engineering.

\subsection{Biocompatibility of chitosan}

When biomaterial is implanted in the body, adverse reactions, such as immune exclusion and cross infection, may occur owing to the human body's own defense system. The grade of cell bonding and spreading to the implantation biomaterial will affect their proliferation and differentiation, ${ }^{44}$ which further affects the repair processes. As a biomaterial, chitosan has been shown to have excellent biocompatibility. ${ }^{45}$ Zhang et al. ${ }^{46}$ indicated that the first reaction of the body towards an implant depends on its surface properties, and explored the biocompatibility of chitosan-based material with protein adsorption and cell culture. The results showed that the addition of polyethylene glycol (PEG) could significantly improve protein adsorption and cell adhesion, growth, and proliferation. Chitosan supports both osteoblastic and osteoclastic cell growth. ${ }^{47}$ Chen et $a l .{ }^{14}$ described the status of human skin fibroblast growth on chitosan microcarriers. After a 24 hour incubation, some cells had attached closely to the surface of the microcarriers (Fig. 5a). After 120 hours, the cells had almost covered the microcarrier surface (Fig. 5b). These results supported the biocompatibility of CS towards human cells. Chatelet et al. ${ }^{48}$ found that the degree of acetylation (DA) of chitosan films had an inversely proportional relationship with cell adhesion and proliferation, meaning that a lower DA resulted in higher cell adhesion. The charge density of chitosan increased with decreasing DA, which reinforced cell adhesion. Thorat et al. ${ }^{\mathbf{4 9}}$ incubated magnetic nanoparticles (MNPs) and chitosan-MNPs with L929 HeLa and MCF7 cells at different concentrations and incubation times under a simulated environment in vivo to explore whether chitosan-encapsulated MNPs affect cellular activity. Cell growth and death were tested to measure the cell viability, with the results (Fig. 6) showing that cell viability increased after chitosan coating, which indicated that chitosan coating increased the biocompatibility. Malafaya et al. ${ }^{\mathbf{5 0}}$ comprehensively explored the in vivo biocompatibility of chitosan particles implanted in animals. After two weeks of implantation, connective tissue was growing and neovascularization had increased between the particles of the scaffold. After three months of implantation, the general expression of von Willebrand Factor (vWF), observed one week after implantation due to the initially formed clot, had decreased, which supported that the implanted chitosan particle scaffold stimulated neovascularization. Remarkably, no angiogenic growth factor or previously seeded angiogenic cells were used in this study. This research showed that chitosan is a promising biomaterial for cartilage defect repair considering the factors mentioned above that prevent cartilage from self-repairing.

\subsection{Biodegradability}

There are three biomaterial phases in tissues, namely, tissue removal, tissue replacement, and tissue regeneration. The main purpose of the last phase is assisting or enhancing the body's own reparative capacity. ${ }^{51}$ Therefore, the biodegradability of biomaterials is vital for regeneration after implantation in the human body and for inducing tissue self-regeneration. An appropriate biodegradability rate is required to match the rate of tissue regeneration. ${ }^{52}$ Rapid degradation of the scaffold affects the adhesion of chondrocytes, while slow degradation hinders cell proliferation and matrix secretion. ${ }^{53}$ Furthermore, using degradable biomaterial appropriately is an effective way to reduce the infection risk. ${ }^{54}$ Chitosan is a polysaccharide, which means it contains breakable glycosidic bonds. ${ }^{55}$ Chitosan is known to be degraded in vertebrates predominantly by lysozyme and certain bacterial enzymes in the colon. ${ }^{56}$ The biodegradability rate of chitosan in living organisms mainly depends on the degree of deacetylation (DD) and average molecular weight $\left(M_{\mathrm{W}}\right),{ }^{9}$ which affect the affinity between enzyme and substrate. ${ }^{57}$ Increasing the DD decreases the degradation rate ${ }^{58}$ because the crystallinity of chitosan, a semi-crystalline polymer, decreases with increasing DD. However, polymer crystallinity is inversely proportional to the biodegradation activity. ${ }^{55}$ The
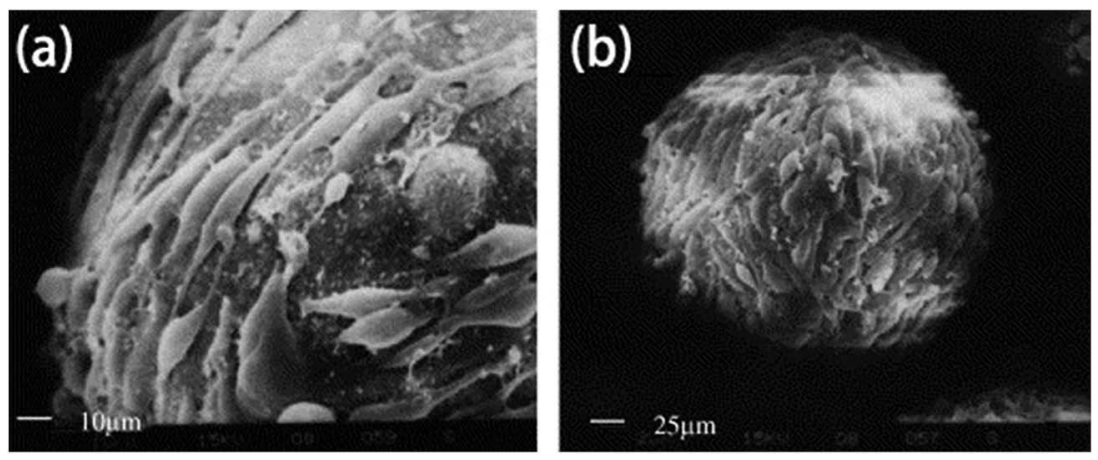

Fig. 5 SEM micrographs of chitosan microcarriers adhered to different growth progressions of human skin fibroblast on the bead surface. (a) Fibroblast after $24 \mathrm{~h}$ of incubation. (b) Fibroblast after $120 \mathrm{~h}$ of incubation. ${ }^{14}$ 

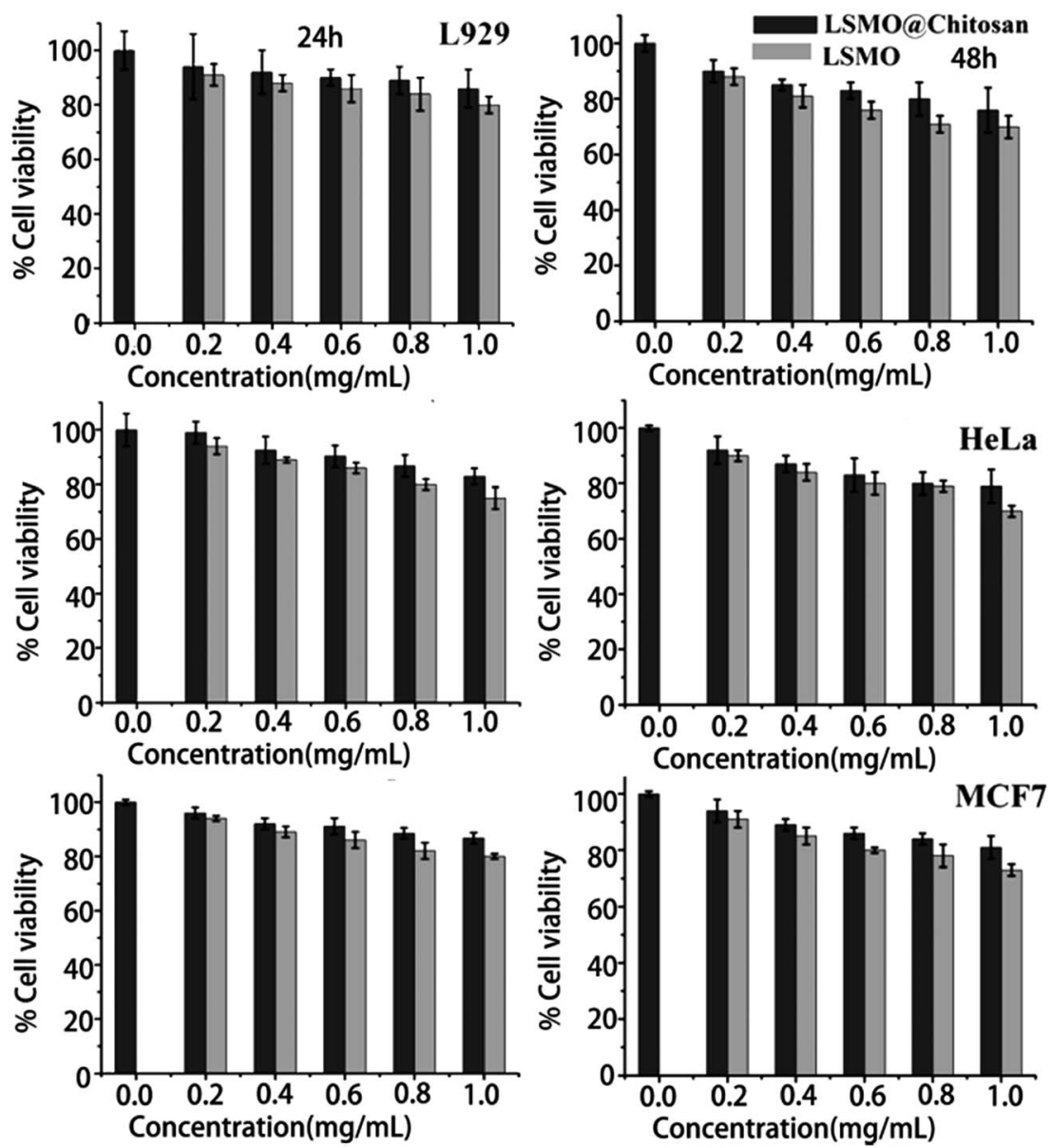

Fig. 6 Biocompatibility of MNPs and CH-MNPs. Cell viability data for MNPs and CH-MNPs for 24 and 48 h on L929, HeLa, and MCF7 cells. Values are expressed as mean $\pm \mathrm{SD}(n=3), \mathrm{LSMO}\left(\mathrm{La}_{0.7} \mathrm{Sr}_{0.3} \mathrm{MnO}_{3}\right)^{49}$

degradation rate reflects the extent of degradation within a certain time period. The molecular weight of chitosan affects its chain flexibility in solution, which in turn affects its affinity for enzymes in hydrolysis reactions. ${ }^{57}$ Jin Li prepared chitosans with different $M_{\mathrm{W}} \mathrm{S}$ and the same DD through ultrasonic degradation to explore the connection between $M_{\mathrm{W}}$ and degradation, which showed that a lower $M_{\mathrm{W}}$ resulted in a faster degradation rate. To summarize, chitosans with lower DDs and $M_{\mathrm{W}} \mathrm{S}$ are more susceptible to enzymatic degradation. ${ }^{57}$ Therefore, the chitosan degradation rate can be altered by adjusting the DD or $M_{\mathrm{W}}$.

Chitosan is mainly degraded by lysozyme hydrolysis, with its by-products exhibiting no pyrogen activity, toxicity, or mutation effect on implanted cells. ${ }^{59}$ Li et al. ${ }^{60}$ studied the metabolism of chitosan after muscle implantation in rat through fluorescence labeling. The result showed that chitosan is gradually distributed to serum and major organs (liver, spleen, kidney, heart, and brain) after implantation. Although the $M_{\mathrm{w}} \mathrm{s}$ of chitosan degradation products found in different organs vary, all $M_{\mathrm{W}} \mathrm{S}$ were less than $10 \mathrm{kDa}$, determined from the largest part in organs in a given time of metabolism comparing with dextran. ${ }^{60}$ Furthermore, chitosan and its degraded products could induce gene expression of cells for AC components, such as type II college. ${ }^{61}$

\section{CS composite scaffolds for articular cartilage defect repair}

Scaffolds designed for AC tissue engineering should exhibit similar physical structures and chemical compositions to the cartilage matrix. The molecular structure of chitosan is similar to that of glycosaminoglycan (GAG), which constitutes the AC ECM. Therefore, this GAG analog is a good choice to fabricate scaffolds for AC defect repair. When substituting native AC ECM, scaffolds should be able to: (i) match up with the native tissue and possess sufficient strength to support cell growth; ${ }^{62}$ (ii) generate a highly hydrated environment that allows for the appropriate exchange of nutrients, electrolytes, oxygen, metabolic waste, and small molecule mediators of cell viability, differentiation, and function; (iii) establish intimate cell-matrix contact to ensure optimal cell viability, differentiation, and function; and (iv) seamlessly integrate with adjacent cartilage tissue and adhere to subchondral bone. ${ }^{24}$ Although CS has superior bioproperties as a biomaterial, it has drawbacks when applied to cartilage tissue engineering. These requirements can be tuned by cross-linking with other polymers and bioceramics. ${ }^{63}$ In this section, we review recent studies on materials composited with CS. 


\subsection{Composites with polymers}

Polymers can be classified into naturally derived polymers and synthetic polymers according to their source. When applied to AC defect repair, natural polymers, such as collagen and gelatin, maintain good cytocompatibility, but have poorer mechanical stability or are easily degraded. Meanwhile, synthetic polymers, including poly-lactic acid (PLA) and poly-caprolactone, have the opposite properties to natural polymers. ${ }^{64}$

\subsubsection{Natural and nature-derived polymers}

4.1.1.1 CS/collagen. As mentioned above, collagen is a major component of AC-specific ECM. It is reported that collagen, typically type II, forms a framework to support the structure and normal function of AC. ${ }^{65}$ Furthermore, collagen is a factor that induces chondrogenesis, both in vitro and in vivo, ${ }^{66}$ with the water uptake ability persisting. However, collagen has a rapid degradation rate and low mechanical strength. ${ }^{67}$ Tangsadthakun et $a l .{ }^{68}$ composited chitosan with collagen at different viscous grades and studied the degradation behavior of the composite scaffolds in vivo and in vitro. The results showed that chitosan with low $M_{\mathrm{W}}$ could improve the compressive modulus and degradation. Furthermore, the collagen/chitosan dosage ratio of $7: 3$ significantly favored cell adhesion and proliferation on the scaffold.

4.1.1.2 CS/gelatin. Gelatin is a collagen derivative. Denaturation reduces the antigenicity caused by animal collagen, and gelatin is cheaper than collagen. Suh et al. ${ }^{69}$ obtained CSgelatin scaffolds by freeze-drying the mixed solution and crosslinking using water-soluble carbodiimide. Sechriest et al. ${ }^{\text {7o }}$ reported that chondrocytes grow slowly on chitosan due to its positive charge. As gelatin is negatively charged, the ionic interaction between these two materials could improve the properties of both for AC defect repair. In the study of cell growth in vitro, cell attachment on C1G1WSC (CS/gelatin = $1: 1$, water-soluble crosslinked) and its films was similar to that on TCPS (blank well) after $24 \mathrm{~h}$, and the advantage of the gelatin composite was clear after $48 \mathrm{~h} .^{71}$ Xia et al. ${ }^{72}$ prepared CS-gelatin $(1: 1)$ porous scaffolds by freezing and lyophilizing a chitosangelatin solution in precooled glass dishes. Pore sizes ranging from 60 to $200 \mu \mathrm{m}$ in diameter were obtained. The seeded chondrocytes could adhere, spread, multiply, and secrete their matrices onto the porous chitosan-gelatin scaffolds. ${ }^{72}$ However, chitosan did not promote chondrocyte adhesion, differentiation, and proliferation, or matrix secretion. Therefore, the authors could not conclude that gelatin blending optimized chitosan for articular defect repair.

4.1.1.3 CS/alginate. Alginate is a family of poly-anionic copolymers derived from brown sea algae. Takahashi et al. ${ }^{73}$ has performed much work on CS/alginate composite scaffolds. The ionic interaction between the negatively charged carbonyl group $(-\mathrm{COOH})$ of alginate and the positively charged amino group $\left(-\mathrm{NH}_{2}\right)$ of chitosan forms the CS/alginate complex. This leads to a significant increase in the Young's modulus and yield strength of the materials. ${ }^{74} \mathrm{Li}$ et al. also studied and compared chondrocyte cell attachment and proliferation on porous chitosan and CS-alginate. SEM images of chondrocyte cells grown on chitosan-alginate and chitosan scaffolds after 14 days of cell culture are shown in Fig. 7, with the blend scaffold showed significantly improved cellular compatibility. ${ }^{75}$ Furthermore, Tığlı et al. ${ }^{76}$ prepared composite scaffolds by introducing chitosan into an alginate matrix in semi IPN form. This type of CS/ alginate scaffold showed improved cell functionality and phenotype retention.

Li et al. ${ }^{77}$ also studied CS/alginate hybrid scaffolds, comparing the swelling behavior of the composite and chitosan scaffolds. Research ${ }^{78}$ has indicated that initial swelling can promote cell attachment and growth, with subsequent stabilization helping to maintain the mechanical properties. Chitosan swells readily in biological fluids, while the alginate composite stabilized the overall size after initial swelling throughout the study period ( 6 weeks) owing to the interaction of amine groups on chitosan with carboxyl groups on alginate. ${ }^{77}$

4.1.1.4 CS/silk fibroin. Bhardwaj et al. ${ }^{79}$ prepared silk fibroin (SF) using a freeze drying method and explored the in vitro degradation of SF/CS blend scaffolds with different concentrations. The chitosan degradation rate depends on the DD. ${ }^{80}$ The DD of chitosan in this study was $85 \%$. The scaffold weight loss and change in $\mathrm{pH}$ in $0.05 \mathrm{M}$ PBS containing $1.6 \mu \mathrm{g} \mathrm{mL} \mathrm{m}^{-1}$ of lysozyme $v s$. pure PBS are shown in Fig. 8. The result indicated that the addition of silk fibroin slowed scaffold hydrolysis in lysozyme, and hindered degradation in PBS ( $\mathrm{pH}$ 7.4). Therefore, the biodegradation time of the scaffolds was increased. ${ }^{79}$ In another study evaluating the chondrogenic proliferation and differentiation of rat mesenchymal stem cells on SF/CS blended porous scaffolds, a significant difference was found between the proliferation rates of SF/CS blended scaffolds and silk fibroin scaffolds. ${ }^{81}$ Li et al. ${ }^{62}$ explored the relationship between the $\mathrm{SF} /$
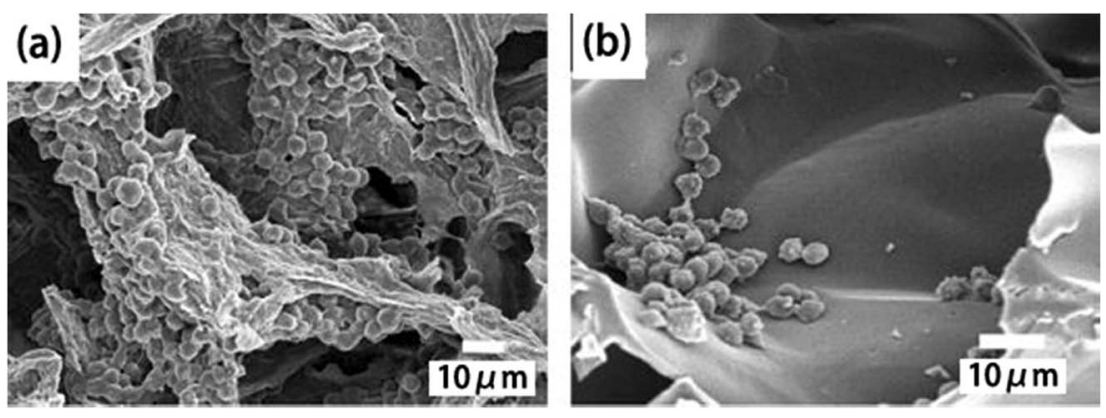

Fig. 7 SEM images of chondrocyte cells grown on (a) chitosan-alginate and (b) chitosan scaffolds after 14 days of cell culture. ${ }^{75}$ 

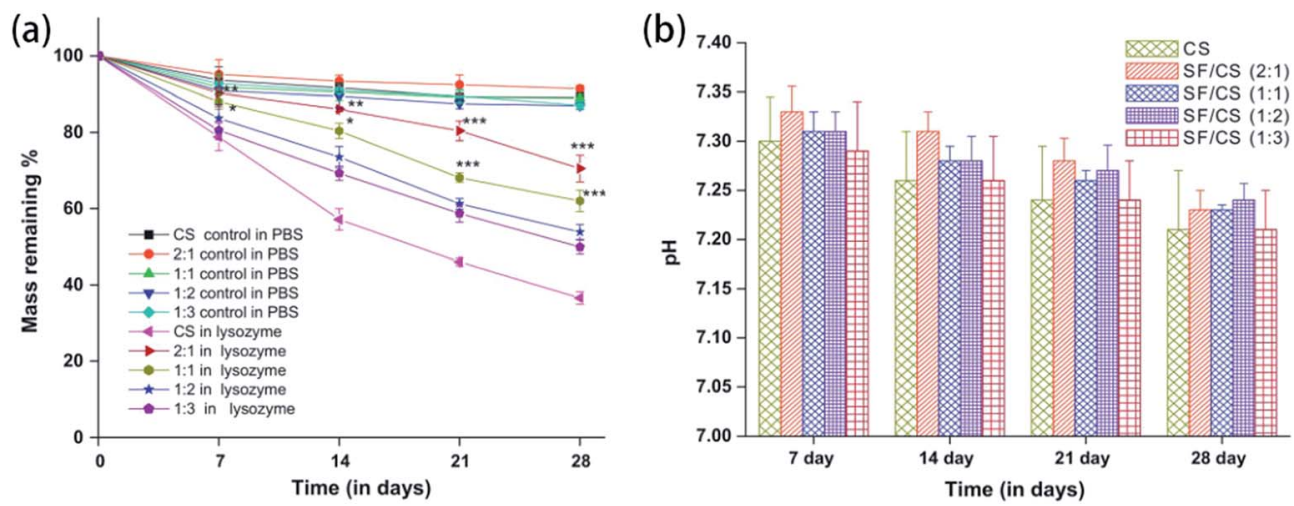

Fig. 8 (a) Degradation behavior and (b) change in $\mathrm{pH}$ of solutions of SF/CS blended scaffolds in $0.05 \mathrm{M} \mathrm{PBS} \mathrm{containing} 1.6 \mu \mathrm{g} \mathrm{mL}^{-1}$ of lysozyme or pure PBS $(\mathrm{pH} 7.4)$ at $37^{\circ} \mathrm{C}^{79}$

CS ratio and the mechanical properties of the hybrid scaffolds, with increasing CS content found to induce a significantly higher compressive modulus and compressive strength.

\subsubsection{Synthetic polymers}

4.1.2.1 CS/poly-caprolactone (PCL). PCL is obtained from the ring-opening polymerization of six-membered lactone, $\varepsilon$-caprolactone $(\varepsilon-\mathrm{CL})$. PCL hydrolysis yields 6-hydroxycaproic acid, an intermediate of w-oxidation, which enters the citric acid cycle and is completely metabolized. ${ }^{82}$ Woodruff et al. ${ }^{83}$ obtained $\mathrm{CS} /$ poly(e-caprolactone) (PCL) poly( $\varepsilon$-caprolactone) blended 3D fiber-mesh scaffolds and studied their properties in $\mathrm{AC}$ application. PCL was found to alter the physicochemical and mechanical characteristics of the scaffold, which could provide a gap because of the brittleness in the wet state $(40-50 \%$ of strain at break) of CS scaffolds ${ }^{84}$ for application in AC regeneration. Furthermore, the positive charge, biocompatibility, and biodegradation of chitosan would compensate for the drawbacks of PCL, such as hydrophobicity. The results showed that blending improved the cell spreading and did not affect cell survival or impair metabolic activity. CS showed the best physiochemical and biological properties. ${ }^{85}$

4.1.2.2 CS/poly-lactic acid (PLA). PLA is thermoplastic biodegradable polymer produced synthetically by the polymerization of lactic acid monomers or cyclic lactide dimers. Lactic acid is produced by the fermentation of natural carbohydrates, such as maize or wheat. ${ }^{82}$ PLA is biodegradable, recyclable, and compostable, and hydrolyzes to its constituents when implanted in the human body. The degradation products of PLA are non-toxic and will be excreted. ${ }^{86}$ There is evidence that PLA is not a promising choice for AC repair scaffold alone, with the PLA matrix shown to be too hard, resulting in interference with the repair process. ${ }^{87}$ PLA appears to be a valid choice for combination with the low compression resistance ability of chitosan scaffold to fabricate a more stable skeleton when blended.$^{88}$ Therefore, scaffolds that possesses higher porosity or a relatively larger pore size favor chondrocyte adhesion, proliferation, and nutrient exchange. Lou et al. ${ }^{89}$ added short chitosan fiber into PLA to obtain hierarchical porous scaffolds. The porosity of the prepared PLLA/CS composite scaffolds was over 94\%. Furthermore, the addition of chitosan improved the compressive modulus and protein adsorption while stabilizing the $\mathrm{pH}$ of the microenvironment under degradation.

Other synthetic polymers have been combined with chitosan to form polyelectrolyte complex scaffolds studied in cartilage repair tissue engineering. Examples include poly(glutamic acid) ${ }^{90}$ poly(ethylene oxide), ${ }^{91}$ and copolymers. When composited with chitosan, synthetic polymers provide mechanical support to the scaffolds, facilitating the formation of hybrid scaffolds into compatible shapes and affording hybrid sponges with good mechanical properties. ${ }^{92}$

\subsection{Composites with bioceramics}

4.2.1 CS/calcium phosphate (CPC). CPC is highly promising for use in human body tissue repair. Composite CScalcium phosphate scaffolds are typically fabricated using coprecipitation methods. ${ }^{93}$ Combining chitosan with calcium phosphate enhances its strength and osteoconductivity. Coating the scaffold with type I collagen makes the surface hydrophilic, which improves cell adhesion..$^{94} \mathrm{Xu}$ et al. ${ }^{95}$ mixed calcium phosphate powder with chitosan using different powder/liquid ratios and altered the macropore volume of the scaffold using different mannitol templates. The incorporation of chitosan enhanced the flexural strength and elastic modulus compared with the pure CPC scaffold, reducing the natural fragility of the CPC bioceramics.

4.2.2 $\mathrm{CS} /$ calcium polyphosphate (CPP). CPP is biodegradable and can eventually be replaced by the repaired tissue. The degradation products of CPP include calcium and phosphate, which are elements essential to organisms. Furthermore, calcium and phosphate do not induce inflammatory reactions. ${ }^{96}$ Kandela et al..$^{97}$ explored a biphasic construct containing a CS/ CPP scaffold and its ability to repair a full thickness osteochondral defect in a sheep knee (stifle). The change in the cartilage tissue after scaffold implantation was studied. ${ }^{97}$ The results showed that the implantation steadily integrated with the adjacent cartilage.

4.2.3 CS/hydroxyapatite (HA). Another bioceramic, hydroxyapatite, was studied by Oliveira et al. ${ }^{98}$ because hydroxyapatite has a similar $\mathrm{Ca} / \mathrm{P}$ ratio (1.67) to AC-specific ECM. Tsiourvas et al. ${ }^{99}$ obtained CS/HA composite scaffolds by 

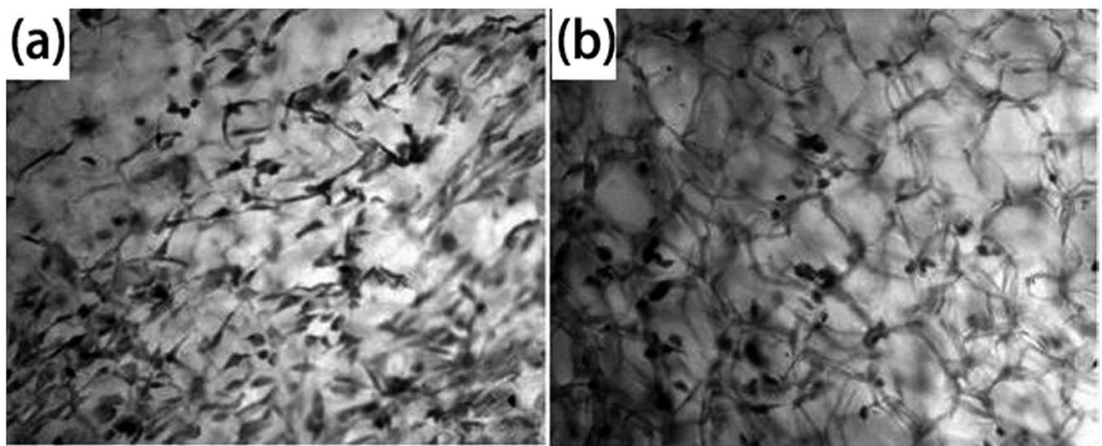

Fig. 9 Wright's stain images of cells grown on scaffolds (original magnification, $200 \times$ ). (a) HA/CS composite scaffolds, (b) chitosan scaffolds. ${ }^{100}$ According to the reference cited, (a) and (b) have the same original size of $5.87 \mathrm{~cm} \times 7.32 \mathrm{~cm}$.

dispersing HA nanoparticles into chitosan acetic acid solution proportionally and molding using a lyophilization method. Larger amounts of added HA resulted in superior mechanical properties of the scaffold. Kong et al. ${ }^{\mathbf{1 0 0}}$ used a novel method to acquire a nano-hydroxyapatite/CS composite solution by sequentially adding certain amounts of $\mathrm{Ca}\left(\mathrm{NO}_{3}\right)_{2}$ aqueous solution and $\left(\mathrm{NH}_{4}\right)_{2} \mathrm{HPO}_{4}$ to chitosan acetic acid solution. The added HA improved the cytocompatibility significantly, as shown in Fig. 9.

\subsection{Other chitosan composite scaffolds}

Other types of chitosan composite scaffold have also been studied for AC defect repair. Man et al. ${ }^{\mathbf{1 0 1}}$ studied allogenic chondrocytes with a chitosan hydrogel (CS)-demineralized bone matrix (DBM) hybrid scaffold (CS/DBM) to repair rabbit cartilage injury. The scaffold was prepared by inserting DBM into CS hydrogel solution followed by incubation at $37{ }^{\circ} \mathrm{C}$ for 10-15 min. ${ }^{101}$ The CS, DBM, and CS/DBM scaffolds were used in vivo to repair rabbit cartilage injury, and the mechanical properties of the repaired tissues compared, as shown in Fig. 10. Microfracture (MF), a common treatment for cartilage defect, ${ }^{\mathbf{1 0 2}}$ served as the control group. The elastic modulus and hardness of the repair tissue were enhanced for CS/DBM compared with CS and DBM alone,${ }^{101}$ resulting in a repair tissue with improved mechanical stability. Furthermore, Shivaprasad et $a .^{\mathbf{4 3}}$ successfully fabricated biocompatible, pristine, and melanin composite silk fibroin biomaterial scaffolds with antioxidant and electroactive properties. The dual antioxidant and electrical conductivity functions of the composite scaffolds supported the proliferation and induced better differentiation of cells. It would be worth studying the effects of melanin on chitosan or chitosan/silk fibroin composite scaffolds discussed above in the field of cartilage tissue engineering.

Scaffolds formed of three or more phases have also been studied. Huaping Tan et al. ${ }^{64}$ have prepared gelatin/chitosan/ hyaluronan scaffolds for cartilage tissue engineering in several studies.

\subsection{Importance of porous structure}

As the scaffold acts as an ECM substitute, it should provide channels for the diffusion of gases and nutrients into the cells, the migration of cells themselves, ${ }^{103}$ and the elimination of metabolic waste. Therefore, the implantable scaffold should be porous. Furthermore, scaffolds bearing pore structures would have improved biocompatibilities. ${ }^{104}$ Several methods have been developed to prepare porous chitosan-based hybrid scaffolds, including freeze ${ }^{99}$ porogen leaching, ${ }^{103}$ and gas forming methods. ${ }^{105,106}$ Scanning topographies of interconnective porous chitosan scaffolds of different sizes are shown in Fig. $11 .^{107}$

Freeze-drying is a method that freezes the solution at a certain temperature, and then lyophilizes the scaffold at (a)

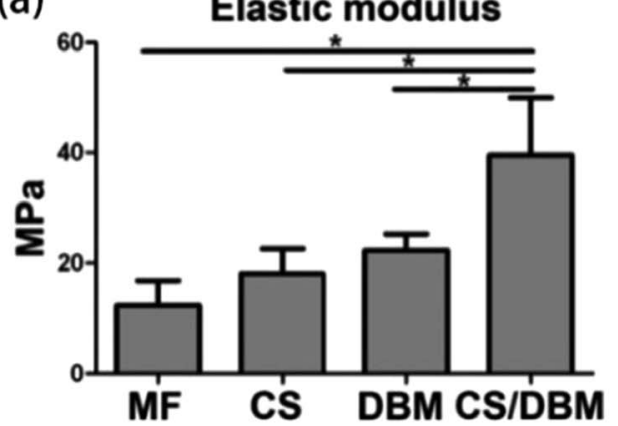

(b)

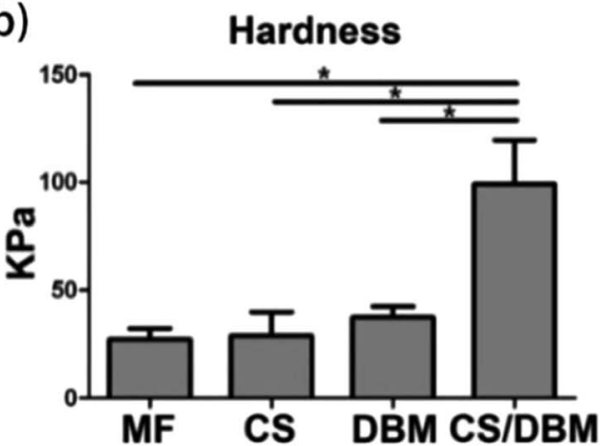

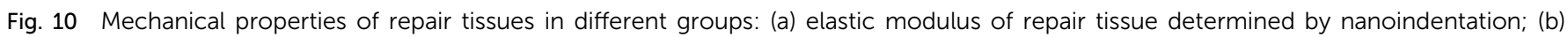
hardness of repair tissue determined by nanoindentation. ${ }^{101}$ 

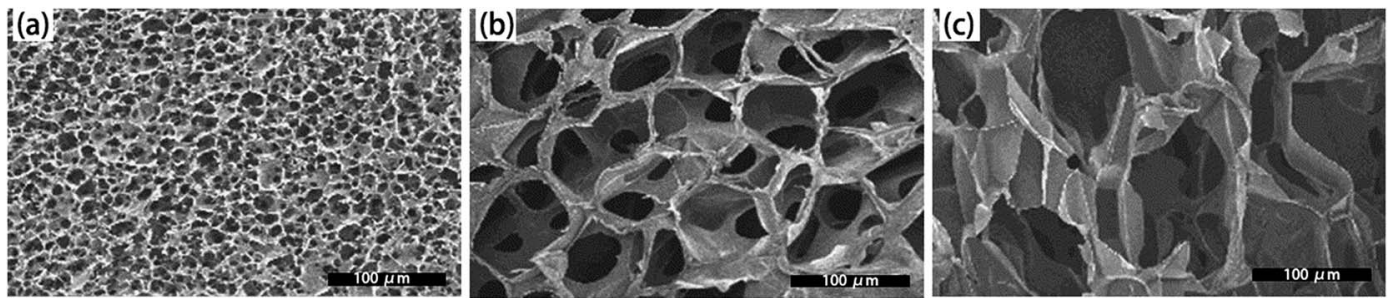

Fig. 11 Morphology of porous chitosan scaffold with pores sizes of (a) $\leq 10 \mu \mathrm{m}$, (b) $10-50 \mu \mathrm{m}$, and (c) $70-120 \mu \mathrm{m}$ in diameter. ${ }^{107}$ Scale bar $=$ $100 \mu \mathrm{m}$.

a certain lower temperature. The solution solvent is sublimated during lyophilization, resulting in the formation of interconnected pores in the matrix. Factors such as the shape and size of ice crystals, type of solvent and polymers, polymeric solution concentration, freezing temperature, and speed of crystallization are known to affect the morphology and porous architecture of scaffolds. ${ }^{108}$ Furthermore, O'Brien et al. ${ }^{109}$ developed a novel freeze-drying method that used a continuous cooling temperature instead of a constant freezing temperature. This process produced more a homogeneous and uniform cellular structure.

Freeze-gelation is a method in which a chitosan-acetic acid solution is immersed in a gelation solution and then frozen ${ }^{110}$ to create a porous structure. The resulting pore size is affected by the freezing temperature. ${ }^{107,111} \mathrm{Hsieh}$ et al. ${ }^{111}$ produced frozen chitosan scaffolds at $-80{ }^{\circ} \mathrm{C},-60{ }^{\circ} \mathrm{C},-40{ }^{\circ} \mathrm{C}$, and $-20{ }^{\circ} \mathrm{C}$ to investigate the relationship between the freezing temperature and tensile properties of the porous chitosan scaffold, with the tensile stress and strain found to increase at higher temperatures.
Freeze-drying is a widely applied method in tissue engineering. ${ }^{112,113}$ However, it is difficult to maintain the shape and topography using this method due to solution shrinkage, resulting in irregular pore sizes. The porogen leaching method ${ }^{92}$ involves mixing the porogen with a matrix, drying the mixture, and then removing the porogen by leaching out with certain solvents. This method has been shown to easily manipulate the pore structure. The pore size was controlled by altering the particle diameter. Commonly used porogens include salts, polyethylene glycol, dibutyl phthalate, and stearic acid. The saltleaching method is a good way to create porosity, because this method uses salt particles instead of organic solvents as porogens. ${ }^{114}$ Commonly used salts are $\mathrm{NaCl}^{115}$ and $\mathrm{CaCl}_{2} \cdot{ }^{116}$

The porogen leaching method cannot obtain completely interconnected pores. Furthermore, porogens can be left behind. 3D printing is more advantageous for obtaining openpore structures. 3D-printed scaffolds allow for rapid and favorable architecture design to optimize cell growth and matrix production, and therefore provide valuable information towards better scaffold design for cartilage repair. ${ }^{117}$

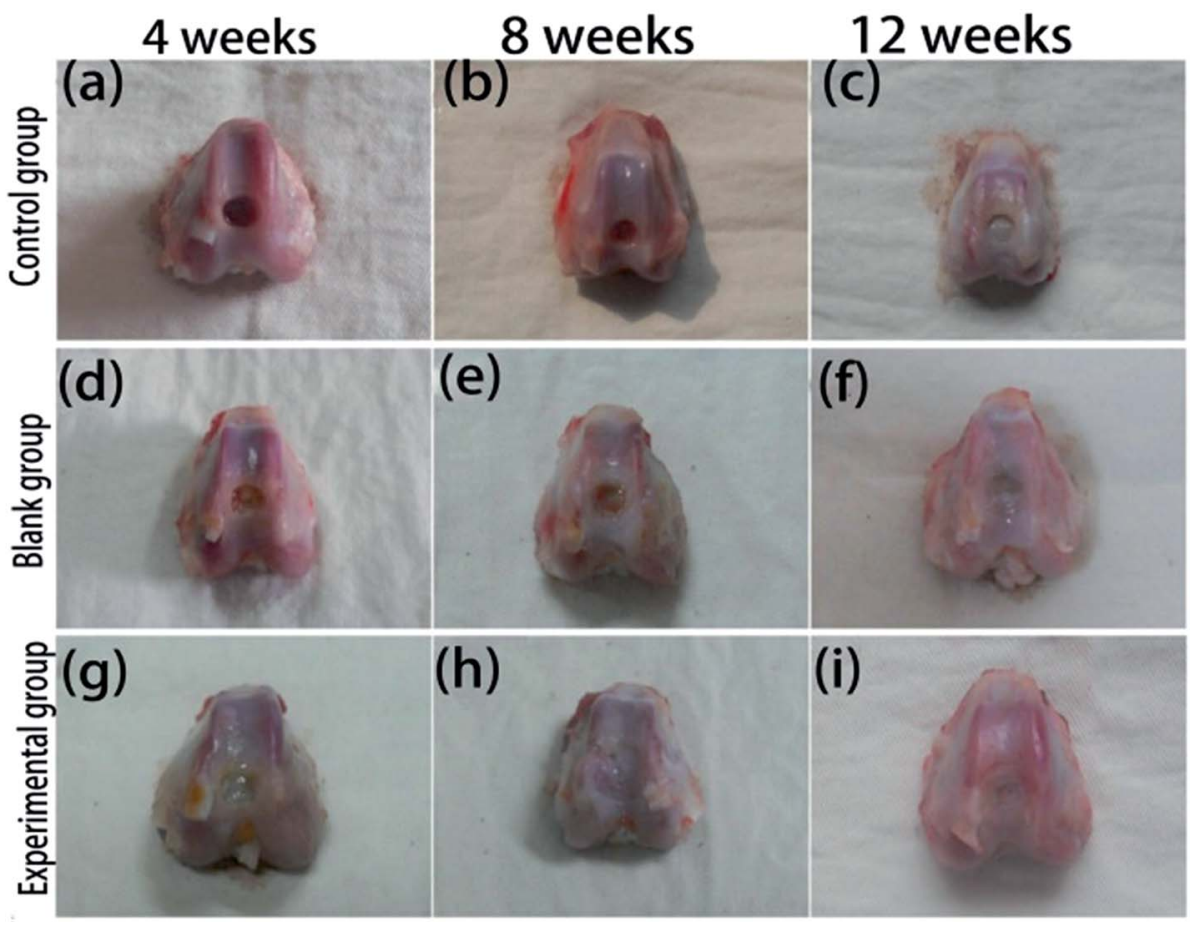

Fig. 12 Gross morphology of repaired cartilage in $(\mathrm{a}-\mathrm{c})$ the control group, $(\mathrm{d}-\mathrm{f})$ the blank group, and ( $\mathrm{g}-\mathrm{i})$ the experimental group at 4, 8, and 12 weeks. ${ }^{122}$ 

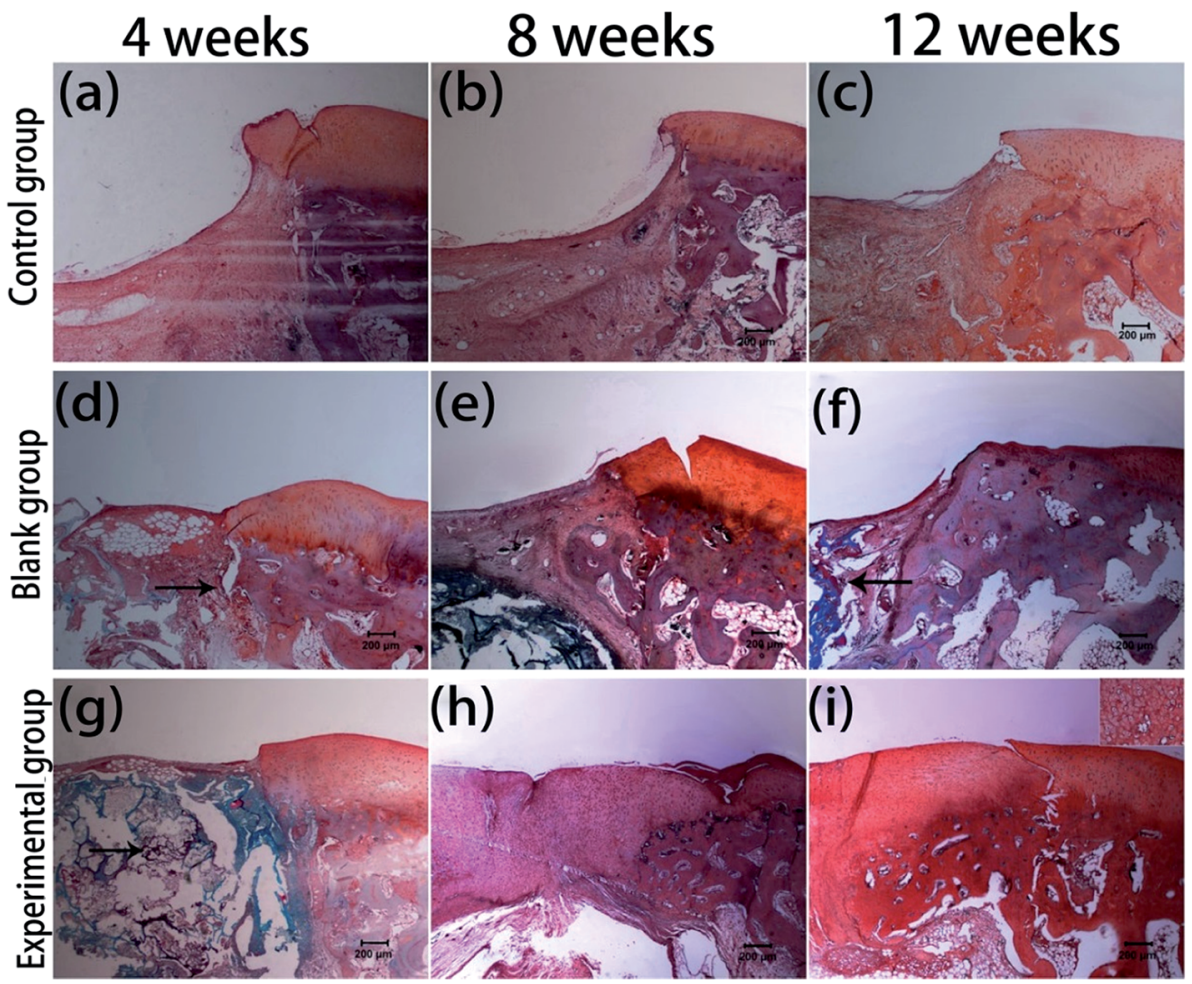

Fig. 13 Safranin-O staining of repaired cartilage in $(a-c)$ the control group, $(d-f)$ the blank group, and $(g-i)$ the experimental group at 4,8 , and 12 weeks. Scale bar $=200 \mu \mathrm{m}$. Arrows show chitosan scaffold. ${ }^{122}$

Furthermore, the pore structure can be designed for 3D printing. Senatov et al. ${ }^{113}$ obtained porous PLA-based scaffolds through 3D printing, in which all pores were interconnected. 3D printing can be performed using indirect and direct methods. In the indirect method, molds are printed using commercially available plaster powder before biodegradable polymers are cast into the printed mold, ${ }^{118}$ while direct $3 \mathrm{D}$ printing eliminates the demolding process. However, the applied polymer materials are limited owing to the organic solvents used in most printheads. Furthermore, 3D printing remains an expensive technique for now.

The gas-forming method is mainly used in polymeric matrices to create pores by dissolving gas into a liquid matrix, then venting the gas under reduced temperature and atmospheric pressure. The most commonly used gas is carbon dioxide $\left(\mathrm{CO}_{2}\right)$ due to its low cost, high stability, and low toxicity. The temperature and pressure could affect the solubility of the gas, and the rate of the depressurization process for gas venting influences the uniformity of the pore structure. ${ }^{105}$

Scaffold pore structures, including pore size, porosity, and homogeneity, have been shown to effect cell adhesion and mechanical properties. Although pores smaller than $50 \mu \mathrm{m}$ have been recommended to improve the biomechanical strength of engineered constructs, ${ }^{107}$ increasing the pore size creates more space for chondrocytes and nutrients. Large pore sizes or porosity in the scaffold favor the exchange of matter. However, this also leads to lower cell attachment and intracellular signaling. ${ }^{119}$ The optimum pore size should allow maximal cell adhesion, growth, and differentiation. The optimum pore size for chondrocyte ingrowth has been identified as $70-120 \mu \mathrm{m} .{ }^{107}$
The preparations of porous structures discussed above have their respective pros and cons. In practice, two or more methods are integrated to optimize scaffolds for AC tissue engineering. Commonly used combinations included porogen leaching/ freeze-drying, ${ }^{120}$ 3D printing/salt leaching, ${ }^{118}$ and cross-linking/ freeze-drying. ${ }^{121}$

\subsection{Implant example}

Biomaterials have a long development-to-application cycle. During the course of study, cell culture and animal implant experiments in vitro or in vivo are typical methods for simulating the effect of biomaterial application. Zhao et al. ${ }^{122}$ transplanted chitosan scaffold with rabbit chondrocytes as an experimental group and pure chitosan scaffold as the blank group into defective rabbit AC. Compared with the control group, which received no implantation, the repairing effect was quite significant. The gross morphology and safranin-O staining of repaired cartilage of the control, blank, and experimental groups at 4, 8, and 12 weeks are shown in Fig. 12 (ref. 122) and 13 (ref. 122).

\section{Conclusion}

$\mathrm{AC}$ is avascular and has almost no self-repair ability. The fluid pressure and compressive tensile properties of the surroundings in vivo and its complex structure are the main challenges facing defect repair. Blend scaffolds that combine chitosan with polymers, ceramics, or other materials have become important in the field of AC defect repair. Chitosan and its composites for 
AC defect repair are reviewed. These materials were notably improved when composited with chitosan by altering its degree of deacetylation, average molecular weight, and form. Scaffolds are usually porous in three dimensions, similar to the AC tissue. Furthermore, as AC was divided into four areas from top to bottom, the development of $3 \mathrm{D}$ porous and gradient chitosan blend scaffolds closer to the ECM is an important direction for further research. Furthermore, the 3D porous scaffold is beneficial for chondrocyte proliferation and differentiation. Porous chitosan composite scaffolds show a good development potential for AC defect repair.

\section{Conflicts of interest}

There are no conflicts to declare.

\section{Acknowledgements}

This work was financially supported by Shenzhen strategic emerging industry development special funds (grant no. JCYJ20150626095244634).

\section{References}

1 D. F. Duarte Campos, W. Drescher, B. Rath, M. Tingart and H. Fischer, Cartilage, 2012, 3, 205-221.

2 G. Ebihara, M. Sato, M. Yamato, G. Mitani, T. Kutsuna, T. Nagai, S. Ito, T. Ukai, M. Kobayashi, M. Kokubo, T. Okano and J. Mochida, Biometerials, 2012, 33, 3846-3851.

3 E. A. Makris, A. H. Gomoll, K. N. Malizos, J. C. Hu and K. A. Athanasiou, Nat. Rev. Rheumatol., 2015, 11, 21-34.

4 L. G. Griffith and G. Naughton, Science, 2002, 295, 10091016.

5 L. Kock, C. C. van Donkelaar and K. Ito, Cell Tissue Res., 2012, 347, 613-627.

6 R. C. Goy, D. D. Britto and O. Assis, Polimeros, 2009, 3, 241247.

7 S. B. Rao and C. P. Sharma, J. Biomed. Mater. Res., 1997, 34, 21-28.

8 S. Shi, J. Jia, X. Guo, Y. Zhao, D. Chen, Y. Guo, T. Cheng and X. Zhang, Int. J. Nanomed., 2012, 7, 5593-5602.

9 T. Kean and M. Thanou, Adv. Drug Delivery Rev., 2010, 62, 311.

10 R. C. Cheung, T. B. Ng, J. H. Wong and W. Y. Chan, Mar. Drugs, 2015, 13, 5156-5186.

11 R. Jayakumar, M. Prabaharan, P. T. Sudheesh Kumar, S. V. Nair and H. Tamura, Biotechnol. Adv., 2011, 29, 322337.

12 A. Abarrategi, Y. Lópiz-Morales, V. Ramos, A. Civantos and L. López-Durán, J. Biomed. Mater. Res., 2010, 95A, 11321141.

13 M. Kumar, React. Funct. Polym., 2000, 46, 1-27.

14 X. Chen, C. Liu, C. Liu, X. Meng, C. M. Lee and H. Park, Biochem. Eng. J., 2006, 27, 269-274.

15 S. V. Madihally and H. W. T. M., Biometerials, 1999, 20, 1133-1142.
16 W. W. Theinhan, Y. Kitiyanant and R. Misra, Mater. Sci. Technol., 2008, 24, 1062-1075.

17 A. E. Sams and A. J. Nixon, Osteoarthr. Cartil., 1995, 3, 47-59.

18 Y. Huang, X. Jin, X. Zhang, H. Sun, J. Tu, T. Tang, J. Chang and K. Dai, Biometerials, 2009, 30, 5041-5048.

19 D. W. Hutmacher, Biomaterials, 2000, 2529-2543.

20 T. R. Seda, S. Ghosh, M. M. Laha, N. K. Shevde and L. Daheron, J. Tissue Eng. Regener. Med., 2009, 3, 348-360.

21 B. A. Rogers, C. L. Murphy, S. R. Cannon and T. W. Briggs, J. Bone Jt. Surg., 2006, 88B, 1670-1674.

22 J. S. Temenoff and A. G. Mikos, Biometerials, 2000, 21, 431440.

23 T. Aigner, Adv. Drug Delivery Rev., 2003, 55, 1569-1593.

24 D. Correa and S. A. Lietman, Semin. Cell Dev. Biol., 2017, 62, 67-77.

25 S. A. Lietman, S. Miyamoto, P. R. Brown, N. Inoue and A. H. Reddi, J. Bone Jt. Surg., Br. Vol., 2002, 84, 600-606.

26 J. S. Temenoff and A. G. Mikos, Biometerials, 2000, 21, 431440.

27 M. Wong and D. R. Carterb, Bone, 2003, 3, 1-13.

28 E. B. Hunziker, Osteoarthr. Cartil., 1999, 7, 15-28.

29 C. Chung and J. A. Burdick, Adv. Drug Delivery Rev., 2008, 60, 243-262.

30 M. Zhao, Z. Chen, K. Liu, Y. Q. Wan, X. D. Li, X. W. Luo, Y. G. Bai, Z. L. Yang and G. Feng, J. Zhejiang Univ., Sci., B, 2015, 16, 914-923.

31 D. Zhao, J. Huang, S. Hu, J. Mao and L. Mei, Carbohydr. Polym., 2011, 85, 832-837.

32 A. P. Martínez-Camacho, M. O. Cortez-Rocha, J. M. Ezquerra-Brauer, A. Z. Graciano-Verdugo, F. Rodriguez-Félix, M. M. Castillo-Ortega, M. S. YépizGómez and M. Plascencia-Jatomea, Carbohydr. Polym., 2010, 82, 305-315.

33 R. Jeuken, A. Roth, R. Peters, C. van Donkelaar, J. Thies, L. van Rhijn and P. Emans, Polymers, 2016, 8, 219.

34 J. K. Suh and H. W. Matthew, Biometerials, 2000, 21, 25892598.

35 F. Comblain, G. Rocasalbas, S. Gauthier and Y. Henrotin, Bio-Med. Mater. Eng., 2017, 28, S209-S215.

36 S. Park, J. Nam, J. Kim, Y. Kim, J. Nah and M. Jang, Int. J. Mol. Sci., 2015, 16, 7995-8007.

37 N. R. Sudarshan and D. G. H. D. Knorr, Food Biotechnol., 2009, 3, 257-272.

38 L. Zheng and J. Zhu, Carbohydr. Polym., 2003, 54, 527-530.

39 I. Younes and M. Rinaudo, Mar. Drugs, 2015, 13, 1133-1174.

40 K. Nishimura, S. Nishimura, N. Nishi, I. Saiki, S. Tokura and I. Azuma, Vaccine, 1984, 2, 93-99.

41 S. Zivanovic, J. Li, P. M. Davidson and K. Kit, Biomacromolecules, 2007, 8, 1505-1510.

42 F. Oprenyeszk, C. Sanchez, J. Dubuc, V. Maquet, C. Henrist, P. Compère and Y. Henrotin, PLoS One, 2015, 10, 1-17.

43 S. Manchineella, G. Thrivikraman, K. K. Khanum, P. C. Ramamurthy, B. Basu and T. Govindaraju, Adv. Healthcare Mater., 2016, 5, 1222-1232.

44 C. D. Reyes, T. A. Petrie, K. L. Burns, Z. Schwartz and A. J. García, Biometerials, 2007, 28, 3228-3235. 
45 S. Hsu, Y. Chang, C. Tsai, K. Fu, S. Wang and H. Tseng, Colloids Surf., B, 2011, 85, 198-206.

46 M. Zhang, X. H. Li, Y. D. Gong, N. M. Zhao and X. F. Zhang, Biometerials, 2002, 23, 2641-2648.

47 G. L. Jones, A. Motta, M. J. Marshall, A. J. El Haj and S. H. Cartmell, Biometerials, 2009, 30, 5376-5384.

48 C. Chatelet, O. Damour and A. Domard, Biometerials, 2001, 22, 261-268.

49 N. D. Thorat, S. V. Otari, R. M. Patil, R. A. Bohara, H. M. Yadav, V. B. Koli, A. K. Chaurasia and R. S. Ningthoujam, Dalton Trans., 2014, 43, 17343-17351.

50 P. B. Malafaya, T. C. Santos, M. van Griensven and R. L. Reis, Biometerials, 2008, 29, 3914-3926.

51 L. L. Hench, Biomaterials, 1998, 18, 1419-1423.

52 Y. M. Yang, W. Hu, X. D. Wang and X. S. Gu, J. Mater. Sci.: Mater. Med., 2007, 18, 2117-2121.

53 C. J. Bettinger, Macromol. Biosci., 2011, 11, 467-482.

54 S. Daghighi, J. Sjollema, H. C. van der Mei, H. J. Busscher and E. T. J. Rochford, Biometerials, 2013, 34, 8013-8017.

55 F. Croisier and C. Jérôme, Eur. Polym. J., 2013, 49, 780-792. 56 M. Rinaudo, Prog. Polym. Sci., 2006, 31, 603-632.

57 J. Li, Y. Du and H. Liang, Polym. Degrad. Stab., 2007, 92, 515-524.

58 M. Dash, F. Chiellini, R. M. Ottenbrite and E. Chiellini, Prog. Polym. Sci., 2011, 36, 981-1014.

59 M. Mattioli-Belmonte, A. Gigante, R. A. Muzzarelli, R. Politano and B. A. De, Med. Biol. Eng. Comput., 1999, 37, 130.

60 H. Li, Z. Jiang, B. Han, S. Niu, W. Dong and W. Liu, J. Ocean Univ. China, 2015, 14, 897-904.

61 A. Lahiji, A. Sohrabi and D. S. Hungerford, Matrix proteins in human osteoblasts, J. Biomed. Mater. Res., 2000, 51, 586595.

62 D. Li, X. Lei, F. He, J. He, Y. Liu, Y. Ye, X. Deng, E. Duan and D. Yin, Int. J. Biol. Macromol., 2017, 105, 584-597.

63 S. Saravanan, R. S. Leena and N. Selvamurugan, Int. J. Biol. Macromol., 2016, 93, 1354-1365.

64 H. Tan, J. Wu, L. Lao and C. Gao, Acta Biomater., 2009, 5, 328-337.

65 T. Minas and S. Nehrer, Orthopedics, 1997, 20, 525-538.

66 L. P. Yan, Y. J. Wang, L. Ren, G. Wu and S. G. Caridade, J. Biomed. Mater. Res., 2010, 95A, 465-475.

67 L. Ma, Biometerials, 2003, 24, 4833-4841.

68 C. Tangsadthakun, S. Kanokpanont, N. Sanchavanakit, R. Pichyangkura and T. Banaprasert, J. Biomater. Sci., Polym. Ed., 2007, 18, 147-163.

69 V. F. Sechriest, Y. J. Miao, C. Niyibizi, A. Westerhausen Larson, H. W. Matthew, C. H. Evans, F. H. Fu and J. K. Suh, J. Biomed. Mater. Res., 2000, 49, 534-541.

70 V. F. Sechriest, Y. J. Miao, C. Niyibizi, A. Westerhausen Larson, H. W. Matthew, C. H. Evans, F. H. Fu and J. K. Suh, J. Biomed. Mater. Res., 2000, 49, 534-541.

71 S. W. Whu, K. Hung, K. Hsieh, C. Chen, C. Tsai and S. Hsu, Mater. Sci. Eng., Proc. Conf., 2013, 33, 2855-2863.

72 W. Xia, W. Liu, L. Cui, Y. Liu, W. Zhong, D. Liu, J. Wu, K. Chua and Y. Cao, J. Biomed. Mater. Res., Part B, 2004, 71, 373-380.
73 T. Takahashi, K. Takayama, Y. Machida and T. Nagai, Int. J. Pharm., 1990, 61, 35-41.

74 Z. Li, H. R. Ramay, K. D. Hauch, D. Xiao and M. Zhang, Biometerials, 2005, 26, 3919-3928.

75 Z. Li and M. Zhang, J. Biomed. Mater. Res., 2005, 75A, 485493.

76 R. S. Tığlı and M. Gümüşderelioğlu, J. Mater. Sci.: Mater. Med., 2009, 20, 699-709.

77 Z. Li, H. R. Ramay, K. D. Hauch, D. Xiao and M. Zhang, Biometerials, 2005, 26, 3919-3928.

78 N. Shanmugasundaram, P. Ravichandran, P. N. Reddy, N. Ramamurty, S. Pal and K. P. Rao, Biometerials, 2001, 22, 1943-1951.

79 N. Bhardwaj and S. C. Kundu, Carbohydr. Polym., 2011, 85, 325-333.

80 T. Kiang, J. Wen, H. W. Lim and K. W. Leong, Biometerials, 2004, 25, 5293-5301.

81 N. Bhardwaj and S. C. Kundu, Biometerials, 2012, 33, 28482857.

82 A. J. Gavasane, Clin. Pharmacol. Biopharm., 2014, 3, 1-7.

83 M. A. Woodruff and D. W. Hutmacher, Prog. Polym. Sci., 2010, 35, 1217-1256.

84 A. Sarasam and S. Madihally, Biometerials, 2005, 26, 55005508.

85 S. C. Neves, L. S. M. Teixeira, L. Moroni, R. L. Reis, C. A. Van Blitterswijk, N. M. Alves, M. Karperien and J. F. Mano, Biometerials, 2011, 32, 1068-1079.

86 R. M. Rasal, A. V. Janorkar and D. E. Hirt, Prog. Polym. Sci., 2010, 35, 338-356.

87 O. Pulliainen, A. I. Vasara, M. M. Hyttinen, V. Tiitu, P. Valonen, M. Kellomäki, J. S. Jurvelin, L. Peterson, A. Lindahl, I. Kiviranta and M. J. Lammi, Tissue Eng., 2007, 13, 1347-1355.

88 A. Haaparanta, E. Järvinen, I. F. Cengiz, V. Ellä, H. T. Kokkonen, I. Kiviranta and M. Kellomäki, J. Mater. Sci.: Mater. Med., 2014, 25, 1129-1136.

89 T. Lou, X. Wang, X. Yan, Y. Miao, Y. Long, H. Yin, B. Sun and G. Song, Mater. Sci. Eng., C, 2016, 64, 341-345.

90 K. Zhang, Y. Zhang, S. Yan, L. Gong, J. Wang, X. Chen, L. Cui and J. Yin, Acta Biomater., 2013, 9, 7276-7288.

91 Y. Kuo and Y. Hsu, J. Biomed. Mater. Res., 2009, 91A, 277-287. 92 G. Chen, T. Ushida and T. Tateishi, Macromol. Biosci., 2002, 2, 67-77.

93 B. M. Chesnutt, A. M. Viano, Y. Yuan, Y. Yang, T. Guda, M. R. Appleford, J. L. Ong, W. O. Haggard and J. D. Bumgardner, J. Biomed. Mater. Res., 2009, 88, 491-502. 94 A. Gottipati and S. H. Elder, 2016, 83-97.

95 H. H. K. Xu and C. G. Simon, Biometerials, 2005, 26, 13371348.

96 R. M. Pilliar, M. J. Filiaggi, J. D. Wells, M. D. Grynpas and R. A. Kandel, Biomaterials, 2001, 22, 963-972.

97 R. A. Kandel, M. Grynpasa, R. Pilliar, J. Lee, J. Wang, S. Waldman, P. Zalzal, M. Hurtig and C. O. S. T. Team, Biometerials, 2006, 27, 4120-4131.

98 J. M. Oliveira, M. T. Rodrigues, S. S. Silva, P. B. Malafaya, M. E. Gomes, C. A. Viegas, I. R. Dias, J. T. Azevedo, J. F. Mano and R. L. Reis, Biometerials, 2006, 27, 6123-6137. 
99 D. Tsiourvas, A. Sapalidis and T. Papadopoulos, Mater. Today Commun., 2016, 7, 59-66.

100 L. Kong, Y. Gao, W. Cao, Y. Gong, N. Zhao and X. Zhang, J. Biomed. Mater. Res., 2005, 75A, 275-282.

101 Z. Man, X. Hu, Z. Liu, H. Huang, Q. Meng, X. Zhang, L. Dai, J. Zhang, X. Fu, X. Duan and C. Zhou, Biometerials, 2016, 108, 157-167.

102 K. B. Lee, H. W. Park, H. J. Cho and J. K. Seon, Am. J. Sports Med., 2015, 43, 1951-1956.

103 H. Wu, Y. Wan, X. Cao and Q. Wu, Acta Biomater., 2008, 4, 76-87.

104 H. J. Chun, G. Kim and C. Kim, J. Phys. Chem. Solids, 2008, 69, 1573-1576.

105 C. Ji, N. Annabi, A. Khademhosseini and F. Dehghani, Acta Biomater., 2011, 7, 1653-1664.

106 H. H. Xu and C. J. Simon, Biometerials, 2005, 26, 1337-1348.

107 D. Griffon, M. Sedighi, D. Schaeffer, J. Eurell and A. Johnson, Acta Biomater., 2006, 2, 313-320.

108 L. L. Reys, S. S. Silva, R. P. Pirraco, A. P. Marques, J. F. Mano, T. H. Silva and R. L. Reis, Eur. Polym. J., 2017, 95, 232-240.

109 F. J. O. Brien, B. A. Harley, I. V. Yannas and L. Gibson, Biometerials, 2004, 25, 1077-1086.

110 M. H. Ho, P. Y. Kuo, H. J. Hsieh, T. Y. Hsien and L. T. Hou, Biometerials, 2004, 129-138.
111 C. Y. Hsieh, S. P. Tsai, M. H. Ho, D. M. Wang and C. E. Liu, Carbohydr. Polym., 2007, 67, 124-132.

112 L. Wang, C. Lu, Y. Li, F. Wu and B. Zhao, RSC Adv., 2015, 78660-78668.

113 F. S. Senatov, K. V. Niaza, M. Y. Zadorozhnyy, A. V. Maksimkin, S. D. Kaloshkin and Y. Z. Estrin, J. Mech. Behav. Biomed. Mater., 2016, 57, 139-148.

114 M. A. Shamekhi, A. Rabiee, H. Mirzadeh, H. Mahdavi, D. Mohebbi-Kalhori and M. Baghaban Eslaminejad, Mater. Sci. Eng., Proc. Conf., 2017, 80, 532-542.

115 S. Khan, M. UlIslam, M. W. Ullah, M. Ikram and F. Subhan, RSC Adv., 2015, 84565-84573.

116 F. S. Palumbo, C. Fiorica, G. Pitarresi, S. Agnello and G. Giammona, RSC Adv., 2015, 5, 61440-61448.

117 D. Rosenzweig, E. Carelli, T. Steffen, P. Jarzem and L. Haglund, Int. J. Mol. Sci., 2015, 16, 15118-15135.

118 H. N. Chia and B. M. Wu, J. Biol. Eng., 2015, 9, 1-14.

119 S. H. Oh, I. K. Park, J. M. Kim and J. H. Lee, Biometerials, 2007, 28, 1664-1671.

120 M. Alizadeh, F. Abbasi, A. B. Khoshfetrat and H. Ghaleh, Mater. Sci. Eng., Proc. Conf., 2013, 33, 3958-3967.

121 S. Dimida, A. Barca, N. Cancelli, V. De Benedictis, M. G. Raucci and C. Demitri, J. Biol. Eng., 2017, 2017, 1-8.

122 M. Zhao, Z. Chen, K. Liu, Y. Q. Wan, X. D. Li, X. W. Luo, Y. G. Bai, Z. L. Yang and G. Feng, J. Zhejiang Univ., Sci., B, 2015, 16, 914-923. 